\section{Nursing Fundamentals: Light between the Shadows of Covid-19 Pandemic}

\author{
Mercedes de Dios-Aguado ${ }^{1 *}$, José Rodríguez-Montejano², \\ María Angustias Torres Alaminos², María Jesús Bocos Regle- \\ ro $^{2}$ and Sagrario Gomez-Cantarino ${ }^{2}$
}

${ }^{1}$ Atención Primaria de Toledo, SESCAM, Spain

${ }^{2}$ Facultad de Fisioterapia y Enfermería, Universidad de Castilla-La Mancha, Campus de Toledo (UCLM), Spain

\begin{abstract}
The main objective of this article is to share the experienceof nursing staff during the COVID 19 pandemic in a Primary Care Centre of the Toledo province the care and attention given to population follow the foundations of the nursing theories Florence Nightingale, Concepción Arenal and Hildegard Peplau. Then through holistic care, nursing staff calm fear and alleviate the pain of suffering person by bringing human warmth, solidarity and fraternity. The year 2020 was not only the International Year of Nursing and Midwifery, but it was also the year of COVID-19 pandemic and bicentenary birth of Florence Nightingale and Concepción Arenal. The Foundation of Humanist women for holistic care of the suffering person and especially of the vulnerable patient remain valid today.
\end{abstract}

\section{Introduction}

Contemporary Nursing, as a health profession, began its journey thanks to Florence Nightingale (1820-1910) [1], who in turn founded the concept of holistic care of the individual [2]. However, the patient-nursing professional relationship began to be established through Hildegard Peplau's Theory of Interpersonal Relationships (1909-1999). This theory analyses the "personal growth" shared by both the patient and the nurse, based on the structured interpersonal relationship in the healthcare process [3]. In Spain, Concepción Arenal was the driving force behind professionalized nursing care [2]. That is why Concepción Arenal is considered the first visiting nurse in Spain [4], although her work is little recognized among health workers [2]. The year 2020 will be remembered for the onset of a

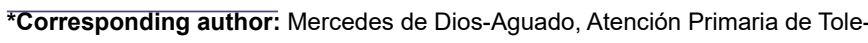
do, SESCAM, Spain, E-mail: mded@sescam.jccm.es

Citation: de Dios-Aguado M, Montejano JR, Alaminos AT, Reglero MJB, Cantarino SG (2021) Nursing fundamentals: light between the shadows of COVID-19 pandemic. J Community Med Public Health Care 8: 090.

Received: August 12, 2021; Accepted: August 27, 2021; Published: September 07,2021

Copyright: (C) 2021 de Dios-Aguado M, et al. This is an open-access article distributed under the terms of the Creative Commons Attribution License, which permits un-restricted use, distribution, and reproduction in any medium, provided the original author and source are credited. pandemic, who's epidemiological epicentre was located in the city of Wuhan (China) in late 2019 and the causative agent is a variety of coronavirus called Sars_Cov_2 [5]. Today, the COVID-19 pandemic continues to collapse the health systems of countless countries, creating an imbalance in the holistic well-being of many groups of people and leading to an increase in mortality in all age groups [6]. Likewise, the year 2020 declared by the World Health Organization, the International Year of Nursing and Midwifery will be remembered with special relevance, due to the involvement of nursing staff in the holistic care of all people affected by Sars-CoV-2. Nurses cared for the most dependent and vulnerable people based on the teachings transmitted by Nightingale [7]. Therefore, it is fair to emphasize that holistic care of the person was carried out in hostile wards of hospitals, in desolate stays of health canters and/or in homes, following the theoretical foundations developed by these nursing theories, whose postulates take special significance, in the field of community care [6]. Therefore, the objective of this article is to know the experienceof a nursing staff during Covid 19 in Primary Care at rural level (Area No. 1 of Toledo), following the model of holistic care proposed by health theorists such as Florence Nightingale, Hildegard Peplau and Concepción Arenal.

\section{Methodology}

This article consists of a narrative research, developed with a qualitative aspect, which involved in socio-sanitary sciences. This methodology is associated with the qualitative approach, as well as the performance of fieldwork and, therefore, the ethnographic description that uses narrative resources [8]. Epistemologically, it is a way to know knowledge within the social sciences, as well as health. Narrating or recounting an experience is one more element in the whole process, constituting a research method [9]. Nursing reflects on the care carried out during the COVID 19 pandemic from the perspective of Nightingale and Arenal. This issue involves addressing the concepts of paradigm according to its model, which generate nursing interventions that reinforce and balance the scientific methods withhuman. In this sense, Arenal promotes and conserves the patient's vital energy. Considering the action that nature exerts on individuals, placing them in the best possible conditions to act on it (Figure 1).

\section{Results \& Discussion}

Implementing, the teachings inherited from Florence Nightingale and Concepción Arenal during the pandemic, has made it possible to take care of people and demonstrate the technical-assistance nurse preparation in the face of a pandemic like that of COVID-19. During the development of our daily activity in the health centre, community, groups, family and individual are the axis of our care, being their training, as well as their participation an indispensable axis in nursing care at the level of Primary Care. Under this premise, and by observing the patient with COVID-19 symptoms, we have appreciated despair, distrust and panic in both verbal and non-verbal communication, before an unknown disease.The fear generates in Patient's decrease ventilatory capacity, discomfort, and even causes suffocation, which results in immediateadmission to the hospital. However, 


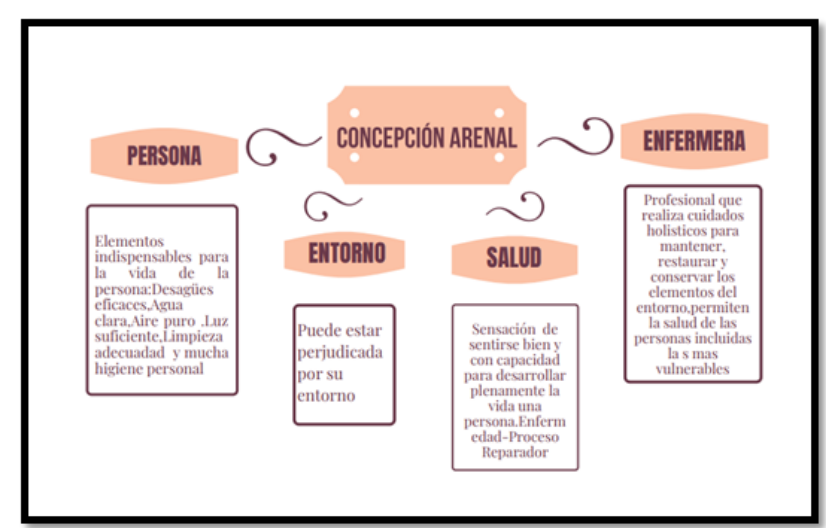

Figure 1: Paradigm of Concepción Arenal.

Source: Prepared by the authors

when the person, feels that he is heard empathicallyand his opinion is respected, he feels accompanied, cared for and protected (holistic care), these attitudes calm his despair, transmit confidence, managing to relax and allow the air to expand his lungs.

So, even if your body isaffected by the SARS-CoV-2 virus, its physical, emotional, intellectual and spiritual component must be kept high. At that time, the person trusts the community nurses, accepting the treatment prescribed by his doctor, as well as the care and health advice that he will have to carry out in his home so that the patient stays in home with greater comfort and without effect Individual health. Following the paradigm of Florence Nightingale and her Theory of the Environment [1], the purpose of nursing professionals will be to influence the environment of the person to solve the affections that manifest the individual and that aggravate their holistic well-being. Likewise, and according to the theoretical postulates of Concepción Arenal, the person is valued individually, supervising their diet to avoid deficient or overeating states. Sometimes, we need to refer to social services, because there are vulnerable families and people with limited financial resources, situations that can make it impossible to achieve good personal hygiene, to provide adequate food or to fix their home, elements that Nightingale defended as indispensable of a person's environment.

In turn, Arenal [10] expressed his concern about the housing conditions of the patients, recommending natural light and fresh air in all rooms of the houses where possible, affecting the ventilation for at least 20 minutes, a fact relevant in the current situation of pandemic, especially in those rooms where several members of the family have been concentrated to carry out their day-to-day work, study, etc. We even incite and supervise the confinement of people who have been diagnosed with COVID 19 and have been prescribed isolationabout the concept of health; Concepción Arenal defines it as the feeling of feeling good, as well as the ability to make the maximum use of the persons faculties [11]. It has been evaluated by us daily through new technologies. Every day we make a phone call to fragile or vulnerable patients with or without COVID pathology 19. Through the telephone interview, we assess and evaluate the person, to recognize warning signs such as fever, diarrhoea, anosmia, ageusia, fatigue, cough, ventilatory capacity, emotional stability, nutritional habits and sleep rhythm. In short, we monitor the patient in order to assess the degree of improvement or worsening, which may motivate a referral to your doctor or recommend going to the centre for an in-situ assessment. The same is due to the theoretical nurse Hildegard Peplau
[3], in whose conjectures he chose to describe the process of nursing relationship in four stages (orientation, identification, exploration and resolution), proposing how the nurse identifies the needs or disorders of the person, so that the person evolves to take full advantage of this relationship, with the goal of obtaining the best possible benefits. Thus, during this pandemic, nurses demonstrated, through holistic care of the individual, it is possible to detect their real problems about their health and care for the person in all its dimensions (bio-psycho-social), managing to act on the social determinants of Lalonde's health, such as lifestyle and environment [12]. The primary care nursing staff has even acted on the health determinant of the health system, through telephone calls as a strategy to make the person feel connected with their reference health professionals and in turn cared for within a safe environment.

We have met individuals during isolation, on multiple occasions, who are living alone, have comfort. The nursing staff, through the telephone call, through voice and active listening, value and perceive the alarm signs of the patient, but at the same time, comfort and care for the patient through the prescribed health advice. In addition, the community environment has a role not only in the patient, but in the patient's caregiver. It is essential to take care of the caregiver, so that informal care is carried out efficiently. Therefore, we put into practice the humanistic model that Arenal bequeathed us, because through active listening we comfort and alleviate the suffering of the person, managing to change the environment of vulnerability in which isolated people find themselves. We even alleviate the hopelessness that the pandemic is causing, because the person in the solitude of the home, between his memories and his absences, with the virus stalking his family, friends or neighbours, taking away his loved ones and unable to give the last goodbye to the next of kin, feels panic to be confined by this disease.

\section{Conclusion}

At this moment the humanistic and holistic model bequeathed by Florence Nightingale, Concepción Arenal and Hildegard Peplau, nursing theorists whose teachings take on infinite value is recognized, thanks to their foundations it is possible to mitigate the pain of the suffering, treating the duel of a broken family in front of an empty chair, in the heat of their home, which will never be the same. The year 2020 was not only the International Year of Nursing and Midwifery, but it was also the year of COVID-19 pandemic and the birth of bicentenary Florence Nightingale and Concepción Arenal.

\section{Acknowledgement}

Our sincere thanks to all patients and their families, teachers and their wisdom, in the times when the shadow of the pandemic has darkened the brightness of our planet. In turn, these lyrics serve as recognition to these illustrious thinkers, for being our light among the cold and dark rooms of health canters, where personal protective equipment is our best allies and the affection towards our patients the best medicine.

\section{References}

1. Nightingale F (1990) Notes on nursing: What it is and what it is not. Spain: Elsevier.

2. Gómez-Cantarino S, de Dios-Aguado M, Peñalver AC, Dominguez-Isabel P, Montejano JR, et al. (2020) Regulation of Spanish Nursing: incorporation to the health profession (1850-1950). Esc Anna Nery 24: e20200053.

3. Peplau HE (1990) Interpersonal relationships in nursing: a conceptual frame of reference for psychodynamic nursing. Barcelona: Salvat. 
Citation: de Dios-Aguado M, Montejano JR, Alaminos AT, Reglero MJB, Cantarino SG (2021) Nursing fundamentals: light between the shadows of COVID-19 pandemic. J Community Med Public Health Care 8: 090.

- Page 3 of 3 .

4. Professional Association of Health Visitors (1934) The Health Visitor. Madrid: Ruíz Ferry graphics.

5. World Health Organization. Coronavirus infections.

6. Ministry of Health, Consumption and Social Welfare-Professionals-Technical documents for professionals-Coronavirus.

7. God-Watered M (2020)Ano of 2020, ponto de inflexão for the World Enfermagem. Histenferm Rev eletrônica 11: 5-6.

8. Goodall HL (2008) Writing Qualitative Inquiry. Self, Stories, and Academic Life. California: Left Coast Press.

9. Webster L, Mertova P (2007) Using Narrative Inquiry as a Research Method. An introduction to using critical event narrative analysis in research on learning and teaching. New York: Routledge.
10. Arenal C (1894) The Visitor of the Poor. Madrid: Victoriano Suarez's bookstore.

11. García Carrasco CA (1861) Charity, philanthropy and charity: memory awarded by the Royal Academy of Moral and Political Sciences, in the course of 1860. Madrid: Printing works of the National College of the Deaf and Mute and the Blind.

12. World Health Organization (2008) Commission on Social Determinants of Health. Fixing inequalities in a generation. Final Report. Geneva: WHO/ PAHO. 


\section{H}

Advances In Industrial Biotechnology | ISSN: 2639-5665

Advances In Microbiology Research | ISSN: 2689-694X

Archives Of Surgery And Surgical Education | ISSN: 2689-3126

Archives Of Urology

Archives Of Zoological Studies | ISSN: 2640-7779

Current Trends Medical And Biological Engineering

International Journal Of Case Reports And Therapeutic Studies | ISSN: 2689-310X

Journal Of Addiction \& Addictive Disorders | ISSN: 2578-7276

Journal Of Agronomy \& Agricultural Science | ISSN: 2689-8292

Journal Of AIDS Clinical Research \& STDs | ISSN: 2572-7370

Journal Of Alcoholism Drug Abuse \& Substance Dependence | ISSN: 2572-9594

Journal Of Allergy Disorders \& Therapy | ISSN: 2470-749X

Journal Of Alternative Complementary \& Integrative Medicine | ISSN: 2470-7562

Journal Of Alzheimers \& Neurodegenerative Diseases | ISSN: 2572-9608

Journal Of Anesthesia \& Clinical Care | ISSN: 2378-8879

Journal Of Angiology \& Vascular Surgery | ISSN: 2572-7397

Journal Of Animal Research \& Veterinary Science | ISSN: 2639-375

Journal Of Aquaculture \& Fisheries | ISSN: 2576-5523

Journal Of Atmospheric \& Earth Sciences | ISSN: 2689-8780

Journal Of Biotech Research \& Biochemistry

Journal Of Brain \& Neuroscience Research

Journal Of Cancer Biology \& Treatment | ISSN: 2470-7546

Journal Of Cardiology Study \& Research | ISSN: 2640-768X

Journal Of Cell Biology \& Cell Metabolism | ISSN: 2381-1943

Journal Of Clinical Dermatology \& Therapy | ISSN: 2378-8771

Journal Of Clinical Immunology \& Immunotherapy | ISSN: 2378-8844

Journal Of Clinical Studies \& Medical Case Reports | ISSN: 2378-880

Journal Of Community Medicine \& Public Health Care | ISSN: 2381-1978

Journal Of Cytology \& Tissue Biology | ISSN: 2378-9107

Journal Of Dairy Research \& Technology | ISSN: 2688-9315

Journal Of Dentistry Oral Health \& Cosmesis | ISSN: 2473-6783

Journal Of Diabetes \& Metabolic Disorders | ISSN: 2381-201X

Journal Of Emergency Medicine Trauma \& Surgical Care | ISSN: 2378-8798

Journal Of Environmental Science Current Research | ISSN: 2643-5020

Journal Of Food Science \& Nutrition | ISSN: 2470-1076

Journal Of Forensic Legal \& Investigative Sciences | ISSN: 2473-733X

Journal Of Gastroenterology \& Hepatology Research | ISSN: 2574-2566
Journal Of Genetics \& Genomic Sciences | ISSN: 2574-2485

Journal Of Gerontology \& Geriatric Medicine | ISSN: 2381-8662

Journal Of Hematology Blood Transfusion \& Disorders | ISSN: 2572-2999

Journal Of Hospice \& Palliative Medical Care

Journal Of Human Endocrinology | ISSN: 2572-9640

Journal Of Infectious \& Non Infectious Diseases | ISSN: 2381-8654

Journal Of Internal Medicine \& Primary Healthcare | ISSN: 2574-2493

Journal Of Light \& Laser Current Trends

Journal Of Medicine Study \& Research | ISSN: 2639-5657

Journal Of Modern Chemical Sciences

Journal Of Nanotechnology Nanomedicine \& Nanobiotechnology | ISSN: 2381-2044

Journal Of Neonatology \& Clinical Pediatrics | ISSN: 2378-878X

Journal Of Nephrology \& Renal Therapy | ISSN: 2473-7313

Journal Of Non Invasive Vascular Investigation | ISSN: 2572-7400

Journal Of Nuclear Medicine Radiology \& Radiation Therapy | ISSN: 2572-7419

Journal Of Obesity \& Weight Loss | ISSN: 2473-7372

Journal Of Ophthalmology \& Clinical Research | ISSN: 2378-8887

Journal Of Orthopedic Research \& Physiotherapy | ISSN: 2381-2052

Journal Of Otolaryngology Head \& Neck Surgery | ISSN: 2573-010X

Journal Of Pathology Clinical \& Medical Research

Journal Of Pharmacology Pharmaceutics \& Pharmacovigilance | ISSN: 2639-5649

Journal Of Physical Medicine Rehabilitation \& Disabilities | ISSN: 2381-8670

Journal Of Plant Science Current Research | ISSN: 2639-3743

Journal Of Practical \& Professional Nursing | ISSN: 2639-568

Journal Of Protein Research \& Bioinformatics

Journal Of Psychiatry Depression \& Anxiety | ISSN: 2573-0150

Journal Of Pulmonary Medicine \& Respiratory Research | ISSN: 2573-0177

Journal Of Reproductive Medicine Gynaecology \& Obstetrics | ISSN: 2574-2574

Journal Of Stem Cells Research Development \& Therapy | ISSN: 2381-2060

Journal Of Surgery Current Trends \& Innovations | ISSN: 2578-7284

Journal Of Toxicology Current Research | ISSN: 2639-3735

Journal Of Translational Science And Research

Journal Of Vaccines Research \& Vaccination | ISSN: 2573-0193

Journal Of Virology \& Antivirals

Sports Medicine And Injury Care Journal | ISSN: 2689-8829

Trends In Anatomy \& Physiology | ISSN: 2640-7752

Submit Your Manuscript: https://www.heraldopenaccess.us/submit-manuscript 